ISSN 1392-3196 / e-ISSN 2335-8947

Zemdirbyste-Agriculture, vol. 103, No. 2 (2016), p. 151-158

DOI $10.13080 / \mathrm{z}-\mathrm{a} .2016 .103 .020$

\title{
Cadmium localization and its toxic effects on root tips of barley
}

\author{
Qiuyue SHI ${ }^{1}$, Junran WANG ${ }^{1}$, Jinhua ZOU ${ }^{1}$, Ze JIANG ${ }^{2}$, Hangfeng WU ${ }^{1}$, Jiayue WANG ${ }^{1}$, \\ Wusheng JIANG ${ }^{1}$, Donghua LIU ${ }^{1}$ \\ ${ }^{1}$ Tianjin Key Laboratory of Animal and Plant Resistance, Tianjin Normal University \\ Tianjin 300387, China \\ E-mail: donghua@mail.zlnet.com.cn \\ ${ }^{2}$ Tianjin Experimental High School \\ Tianjin 300074, China
}

\begin{abstract}
Toxic effects of different cadmium (Cd) concentrations on root tip cells of barley (Hordeum vulgare L.) for 1, $4,12,24,48$ and $72 \mathrm{~h}$ were investigated in order to better understand the mechanisms both in metal toxicity and tolerance. The results indicated that the roots were the main sites of cadmium uptakes. Cadmium ions initially entered elongation zone cells and were accumulated in this area. Then, the cadmium extends up to mature zone and down to meristem zone gradually. The degree of the cell damage in the root tips was associated with the amounts of cadmium absorption and accumulation. After cadmium ions entered meristem zone, cadmium disturbed the mechanisms controlling the organization of microtubule (MT) cytoskeleton and tubulin assembly/disassembly processes. The formation of abnormal MT arrays was formed, including discontinuous wavy MTs and short MT fragments at the cell periphery. The toxic effects resulted in a decrease of mitotic index and inducement of abnormal mitosis, inducing aberrant chromosomes, such as C-mitosis, anaphase bridges and chromosome stickiness. Therefore, MT cytoskeleton can be thought to be one of target sites of cadmium toxicity in root tip cells of plants. The direct cellular evidence of cadmium toxic effects on root tips of barley obtained here is valuable in evaluation of mechanisms both in metal toxicity and tolerance.
\end{abstract}

Key words: Hordeum vulgare, Leadmium ${ }^{\mathrm{TM}}$ Green AM, microtubule, mitosis, propidium iodide.

\section{Introduction}

Cadmium $(\mathrm{Cd})$, at trace levels, has trends to accumulate in soils due to the use of wastewater for irrigation, and application of biosolids and composts from urban wastes (Alloway, 1995). Cadmium can easily be absorbed, and accumulated in plant tissues where root is the primary site of accumulation (Liu et al., 2007). There are some potential mechanisms concerning the detoxification of heavy metals at the cellular level. Heavy metal tolerance in higher plants results from different processes which prevent excess of heavy metals in the cytoplasm and organelles. Cadmium toxicity in many nontolerant plants is thought to be associated with the interference of mitosis (Das et al., 1997; Xu et al., 2009; Zhang et al., 2009; Shi et al., 2014), toxicity of nucleoli (Zhang et al., 2009; Zou et al., 2012; Qin et al., 2013) and influence of numerous physiological and metabolic processes (for review, see Sanità di Toppi, Gabbrielli, 1999). As a result, cadmium in plants generally inhibits growth and development of roots. Microtubules (MTs) play a central role in cell division, cell expansion, cell differentiation and intracellular organization and motility (Wasteneys, Galway, 2003). The movement of chromosome and vesicle transport in secretion, prediction of the alignment of the cell plate and the orientation of the cellulose wall microfibrils are, to varying degrees, mediated by MTs (Hepler, Hush, 1996). In a living cell, MTs are dynamic and their polymerization and depolymerization are affected by heavy metals (Hepler, Hush, 1996; Přibyl et al., 2005; Liu et al., 2009; Jiang et al., 2014). Although there are some reports indicating that the root tip plays a major role in heavy metal perception and response (Jiang et al., 2014), the mechanism concerning heavy metalinduced growth inhibition still poorly understand.

Some higher plants such as Allium cepa, Vicia faba, Hordeum vulgare and Zea mays can provide a useful genetic system for screening and monitoring environmental pollutants (Andrioli et al., 2012). Barley (H. vulgare L.) is well known as a good model plant for the detection of heavy metal pollution in the laboratories (Özkara et al., 2011). The toxic effects of different concentrations of cadmium on $\mathrm{Cd}$ localization, cell damage and cell mitosis and microtubule organization in root tip cells of barley for 1, 2, 12, 24, 48 and $72 \mathrm{~h}$ by means of fluorescence labeling, propidium iodide staining, carbol fuchsin staining and indirect immunofluorescent microscopy were investigated in the present study. The data obtained here will be very useful to better understand the mechanisms of $\mathrm{Cd}$-induced cell toxicity.

\section{Materials and methods}

Culture condition and cadmium (Cd) treatment. The experiment was carried out in Tianjin Key Laboratory of Animal and Plant Resistance, College of Life Sciences, Tianjin Normal University, China in 2015. Healthy equally-sized seeds of barley (Hordeum vulgare L.) were selected and soaked in distilled water for $24 \mathrm{~h}$. After the seeds had been germinated in moistened gauze in the dark 
at $23^{\circ} \mathrm{C}$ for $12 \mathrm{~h}$, they grew in plastic containers containing distilled water at $23^{\circ} \mathrm{C}$ for $24 \mathrm{~h}$, producing roots reaching about $0.6 \mathrm{~cm}$ length. Then the seedlings were exposed to different concentrations of $\mathrm{Cd}$ solutions $(1,10,50$ and $100 \mu \mathrm{M})$ for 24,48 and $72 \mathrm{~h}$. Cadmium chloride $\left(\mathrm{CdCl}_{2}\right)$ was used in the present investigation. The solutions were aerated with pump lines. Control seedlings were grown in distilled water alone. The solutions for the experiment were renewed regularly every $24 \mathrm{~h}$. All treatments were done in three replicates.

Carbol fuchsin-staining. About $0.1 \mathrm{~cm}$ length root tips of barley treated with 1, 10, 50 and $100 \mu \mathrm{M}$ $\mathrm{Cd}$ for 24, 48 and $72 \mathrm{~h}$ were cut at the end of each time interval. Then they were fixed and hydrolyzed. After that they were squashed in carbol fuchsin solution for counting the cell mitosis and observing the variation of chromosome. Approximately 3,000 cells (about 1,000 cells each slide) were observed for calculating mitotic index (MI) of each treatment group at the end of each time interval. The methods are described in more detail by Jiang et al. (2014).

Immunofluorescent microscopy. Meristematic zones of root tips from control and seedlings of barley exposed to $1,10,50$ and $100 \mu \mathrm{M} \mathrm{Cd}$ for 24,48 and $72 \mathrm{~h}$ were cut, respectively and fixed with $4 \%(\mathrm{w} / \mathrm{v})$ paraformaldehyde in phosphate-buffered saline (PBS, $\mathrm{pH}$ 7.0) for $1.5 \mathrm{~h}$ in darkness at room temperature and then they were washed with the same buffer three times $(3 \times 10 \mathrm{~min})$. The immunofluorescent specimens were examined under a fluorescence microscope. The methods are described in more detail (Jiang et al., 2014).

Fluorescence labelling of cadmium and propidium iodide staining. Intact roots treated with $50 \mu \mathrm{M} \mathrm{Cd}$ for $1,4,12,24$ and $48 \mathrm{~h}$ and the plants that were not exposed to cadmium as control plants were stained using the Cd-specific probe Leadmium ${ }^{\mathrm{TM}}$ Green AM solution (Molecular Probes, Life Technologies, USA). The methods are described in more detail (Jiang et al., 2014). To visualize damaged root tip cells induced by cadmium, root tips from plants exposed to the same treatment groups mentioned above were stained with propidium iodide (P4170) (Sigma-Aldrich, Switzerland). These root tips were double stained with fluorescence labelling of cadmium and propidium iodide. Intact cells exhibit green fluorescence due to cadmium specific probe Leadmium $^{\mathrm{TM}}$ Green AM, and propidium iodide provides red fluorescence of nuclei in damaged cells, as propidium iodide has very low penetrability across intact membranes. The fluorescence density was analyzed using "Analyse and Measure" function of the software ImageJ (NIH, USA) to evaluate distribution in the intact roots and the different areas of roots (meristem, elongation and mature zone) of barley seedlings exposed to or without $50 \mu \mathrm{M} \mathrm{Cd}$. The immunofluorescent specimens were examined with a confocal laser scanning microscope Nikon ECLIPSE 90i.

Statistical analysis. Fifteen seedlings were used to each treatment and each treatment was run in triplicate for statistical validity. Results here were analyzed with standard statistical software SPSS and SigmaPlot 8.0 using means \pm standard error (SE). Any differences between treatments were determined using one-way analysis of variance (ANOVA). For equality of averages the $t$-test was applied. Results were considered statistically significant at $P<0.05$.

\section{Results}

Cadmium absorption and distribution. Fluorescence spectra were analyzed from linescanning of meristem, elongation and mature zone in the root tips
(Fig. 1I). There was no green fluorescence (Cd) in control root tips (Fig. 1IA), whereas different fluorescence intensities in the root tips exposed to $50 \mu \mathrm{M} \mathrm{Cd}$ for the different treatment times were detected (Fig. 1IB-F). According to a weak green fluorescence labelling of cadmium observed in the elongation zone cells exposed to $\mathrm{Cd}$ for $1 \mathrm{~h}$ (Fig. 1IB), we suggest that cadmium ions firstly entered and were accumulated in this area. Then, the fluorescence labelling cadmium extends up to mature zone and down to meristem zone gradually (Fig. 1IB-F). The cadmium level still increased when Cd exposure for $48 \mathrm{~h}$ (Fig. 1IF). The fluorescence density analysis of cadmium was analyzed by software Image $J$, confirming the findings mentioned above. The evidence demonstrated that the root tips of barley under cadmium stress could absorb cadmium ions and the amount of $\mathrm{Cd}$ increased significantly $(P<0.05)$ with prolonged exposure (Fig. 1II). Data from Figure 1III showed the distribution of cadmium in the different zones of roots of barley treated with $50 \mu \mathrm{M}$ Cd for different treatment times. Levels of cadmium in different zones of barley roots exposed to $\mathrm{Cd}$ during the 1 to $4 \mathrm{~h}$ period had significant difference $(P<0.05)$ and they were in the order: elongation zone $>$ mature zone $>$ meristem zone, whereas during the $12 \mathrm{~h}$ period the contents were as follows: elongation zone $>$ meristem zone $>$ mature zone. During the 24 to $48 \mathrm{~h}$ period, intense fluorescence in mature zone was found to be weak when compared with the other zones, and the concentration of cadmium in meristem zone was more or less the same as the one in elongation zone (Fig. 1III). There was no significant difference between them, suggesting that both meristem and elongation zone in the roots of barley were the main cadmium absorption and accumulation sites.

Effects of cadmium on cell damage. To visualize damaged root tip cells induced by cadmium, the root tip cells of barley exposed to $50 \mu \mathrm{M} \mathrm{Cd}$ for $0,1,4,12,24$ and $48 \mathrm{~h}$ were stained with propidium iodide (Fig. 2I). Due to propidium iodide entering cells, red fluorescence is an indicator of cell damage. Weak fluorescence was observed in the control roots, suggesting there was some cell damage in root tips during the plant growth period, although the root tip cells were not treated with cadmium (Fig. 2IA).

Different fluorescence intensities were exhibited by the root tip cells of barley exposed to $50 \mu \mathrm{M} \mathrm{Cd}$ for different periods of treatment (Fig. 2IB-F). The lower level of fluorescence intensity was noted in the cells after $1 \mathrm{~h} \mathrm{Cd}$ treatment, revealing that cadmium could induce cell damage as early as $1 \mathrm{~h} \mathrm{Cd}$ exposure (Fig. 2IB). During $4 \mathrm{~h}$ period of treatment, stronger red fluorescence intensity labelling dead cells appeared in the meristem zone (Fig. 2IC). The effect was more pronounced with prolonged exposure. The data from the fluorescence density analysis by software Image $J$ also can confirm the findings (Fig. 1II). During 12 to $48 \mathrm{~h}$ period, the red fluorescence intensity in mature zone obviously increased (Fig. 2ID-F). The sites of cadmium uptake and accumulation are consistent with the distribution of death cells in the root tips of barley. Data from Figure 2II showed the distribution of cell damage induced by cadmium in the different zones of roots of barley. The extent of necrotic cells in elongation zone exposed to cadmium during 1 to $12 \mathrm{~h}$ period was high significantly $(P<0.05)$ when compared with meristem and mature zone, whereas the number of dead cells from meristem zone was increased significantly $(P<0.05)$ after the treatment with cadmium for $24 \mathrm{~h}$.

Effects of cadmium on mitotic index (MI). The MI in the root tips of barley under cadmium stress 

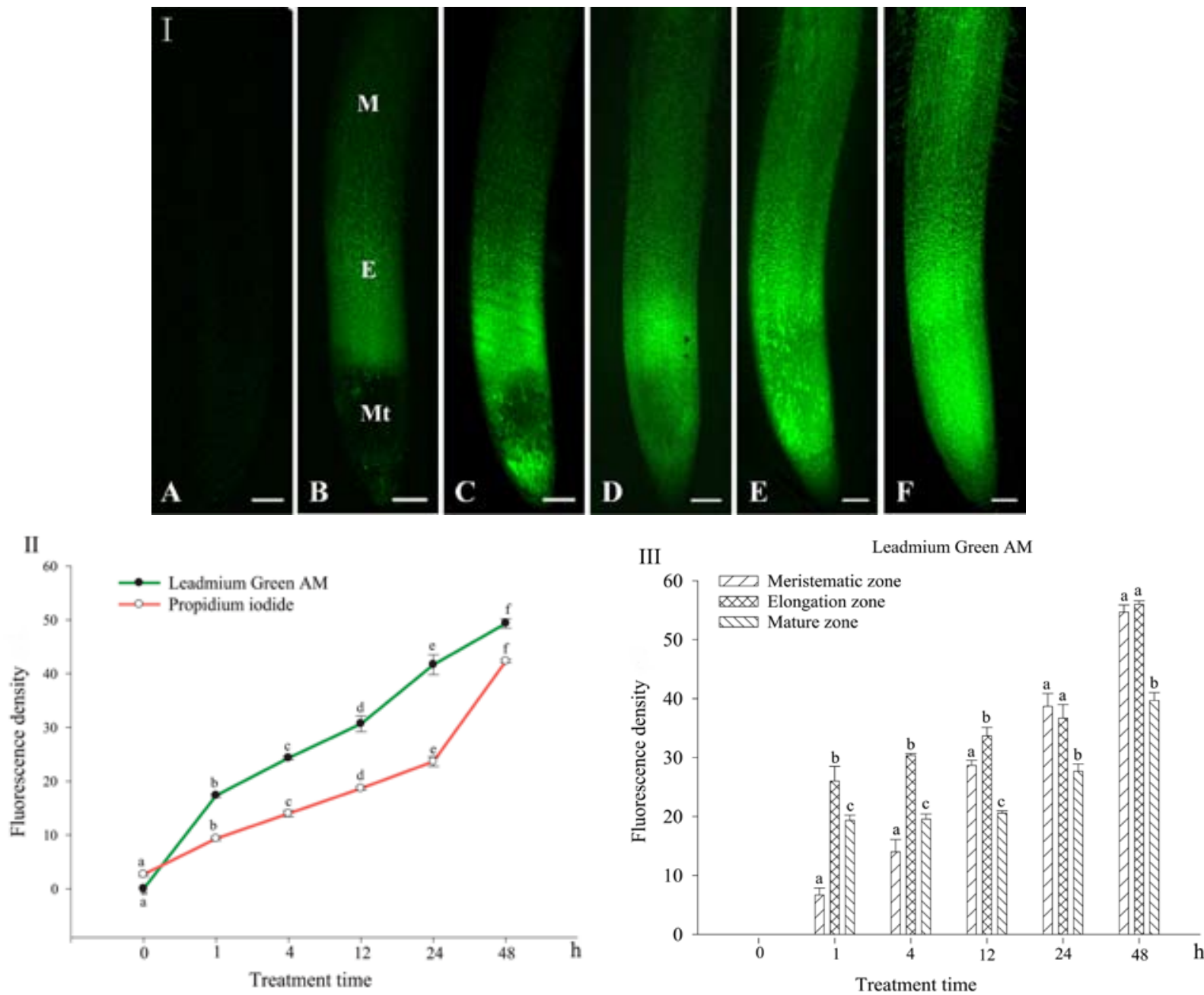

Notes. I. Micrographs of roots from barley exposed to cadmium using Leadmium ${ }^{\mathrm{TM}}$ Green $\mathrm{AM}$ dye. Cadmium detection images of the roots which were pre-treated with $50 \mu \mathrm{M} \mathrm{Cd}$ for $0,1,4,12,24$ and $48 \mathrm{~h}$, respectively (A-F). All images were taken at X4 magnification, and green fluorescence represents the binding of the dye to cadmium; $\mathrm{Mt}$ - meristem zone, $\mathrm{E}$ - elongation zone, $\mathrm{M}$ - mature zone. Scale bars $=200 \mu \mathrm{m}$. II. Relationship between Leadmium ${ }^{\mathrm{TM}}$ Green AM dye and propidium iodide fluorescence density in the intact roots exposed to $50 \mu \mathrm{M} \mathrm{Cd}$ for $0,1,4,12,24$ and $48 \mathrm{~h}$ treatment time. III. Distribution of fluorescence density $(\mathrm{Cd})$ in the different zones of roots of barley treated with $50 \mu \mathrm{M} \mathrm{Cd}$ for $0,1,4,12,24$ and $48 \mathrm{~h}$ treatment time.

Figure 1. Cadmium (Cd) uptake and accumulation in barley roots

decreased progressively as a function of increased cadmium concentration, except for the group exposed to $100 \mu \mathrm{M}$ Cd (Table). The MI can be correlated with the rate of root growth, suggesting that cadmium inhibited root growth of barley due to inhibition of cell division.

Effects of cadmium on chromosome morphology. We investigated changes in the organization and morphology of the chromosomes in barley root tips exposed to the cadmium. The aberrant chromosomes introduced were noted in the root tip cells of barley under cadmium stress. C-mitosis was observed in the root tip cells of all cadmium treated groups of barley. At low cadmium concentration (1 and $10 \mu \mathrm{M}), \mathrm{C}$-mitosis induced by cadmium in the present study is a major type of chromosomal aberration, showing highly condensed chromosomes existed randomly in root tip cells (Fig. 3A). One or more anaphase bridges were found after the $10 \mu \mathrm{M}$ $\mathrm{Cd}$ treatment (Fig. 3B-C). Anaphase configurations with chromosome bridges revealing stickiness were observed at 50 and $100 \mu \mathrm{M} \mathrm{Cd}$ (Fig. 3D). Chromosome stickiness consisted of metaphase (Fig. 3E) and telopase (Fig. 3F) sticky chromosomes. It occurred at high concentration (50 and $100 \mu \mathrm{M})$ of $\mathrm{Cd}$.

The organization of microtubule (MT) cytoskeleton in control cells. Immunofluorescence microscopy has been used to reveal the location of

Table. Effects of cadmium (Cd) on mitotic index (MI) (\%) in the root tip cells of barley

\begin{tabular}{|c|c|c|c|c|c|}
\hline \multirow{2}{*}{$\underset{\mathrm{h}}{\mathrm{Time}}$} & \multicolumn{5}{|c|}{ Treatment $\mu \mathrm{M}$} \\
\hline & control & 1 & 10 & 50 & 100 \\
\hline 24 & $24.96 \pm 0.96 \mathrm{a}$ & $19.45 \pm 0.95 b$ & $12.43 \pm 0.98 \mathrm{c}$ & $7.92 \pm 0.31 \mathrm{~d}$ & $7.64 \pm 0.39 d$ \\
\hline 48 & $19.94 \pm 1.78 \mathrm{a}$ & $14.05 \pm 0.84 b$ & $8.25 \pm 0.33 c$ & $4.20 \pm 0.24 \mathrm{~d}$ & $3.62 \pm 0.24 \mathrm{~d}$ \\
\hline 72 & $13.21 \pm 0.33 \mathrm{a}$ & $11.09 \pm 0.25 \mathrm{~b}$ & $6.71 \pm 0.34 \mathrm{c}$ & $2.61 \pm 0.12 \mathrm{~d}$ & $2.11 \pm 0.09 \mathrm{~d}$ \\
\hline
\end{tabular}

Note. Values followed by the same letters are not significantly different $(P<0.005)$; means \pm standard error, $\mathrm{n}=15$. 

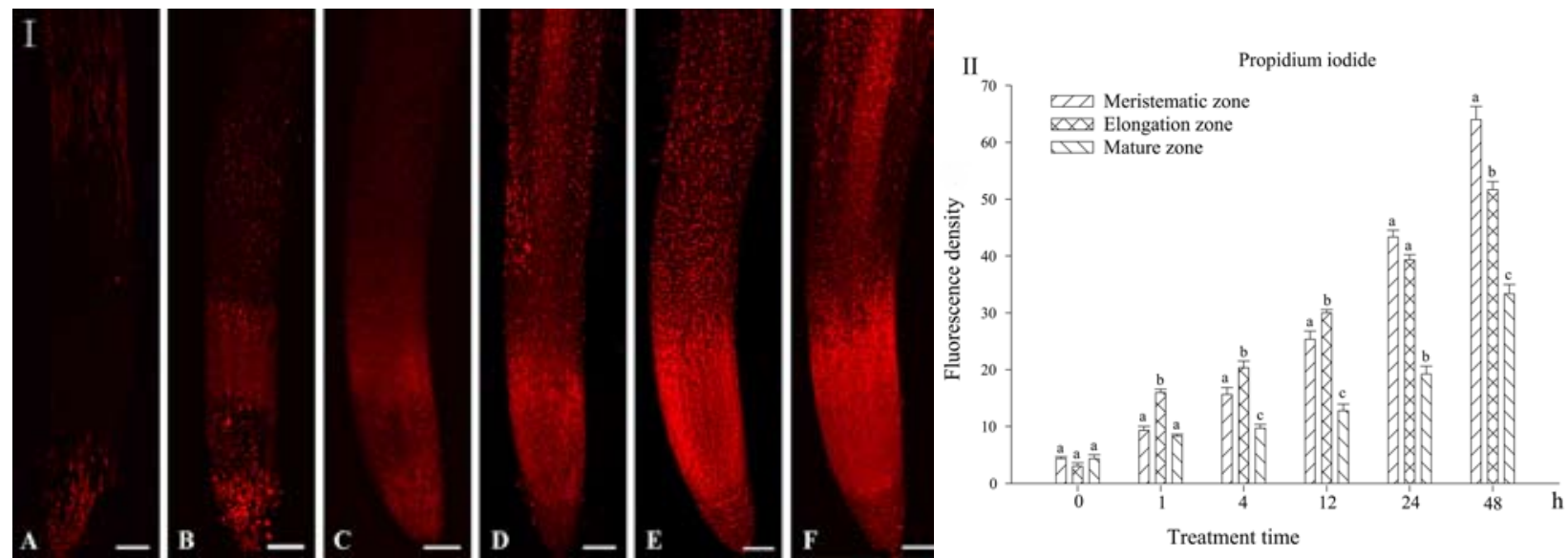

Notes. I. Micrographs of roots from barley exposed to cadmium using propidium iodide. Red fluorescence due to propidium iodide entering cells is an indicator of cell damage, showing status of cell death of the roots exposed to $50 \mu \mathrm{M} \mathrm{Cd}$ for $0,1,4,12,24$ and $48 \mathrm{~h}$, respectively $(\mathrm{A}-\mathrm{F})$. All images were taken at X4 magnification. Scale bars $=200 \mu \mathrm{m}$. II. Distribution of propidium iodide fluorescence density in the different zones of roots of barley treated with $50 \mu \mathrm{M} \mathrm{Cd}$ for different treatment times. Values followed by same letters are not significantly different $(P<0.005)$; means \pm standard error, $\mathrm{n}=15$.

Figure 2. Effects of cadmium $(\mathrm{Cd})$ on cell damage in barley roots

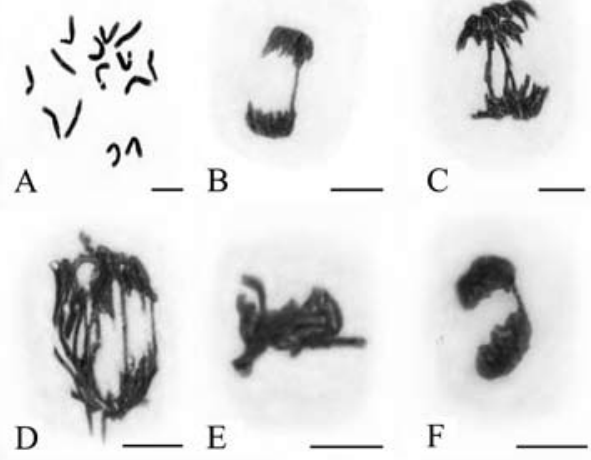

C-metaphase $(1 \mu \mathrm{M} \mathrm{Cd}, 48 \mathrm{~h})(\mathrm{A})$, chromosome bridges $(10$ $\mu \mathrm{M} \mathrm{Cd}, 24 \mathrm{~h})(\mathrm{B}-\mathrm{C})$, sticky chromosome bridges $(50 \mu \mathrm{M} \mathrm{Cd}$, $24 \mathrm{~h})(\mathrm{D})$, sticky chromosome at metaphase $(100 \mu \mathrm{M} \mathrm{Cd}, 24$ h) (E), sticky chromosome at telophase $(50 \mu \mathrm{M} \mathrm{Cd}, 48 \mathrm{~h})(\mathrm{F})$; scale bars $=10 \mu \mathrm{m}$

Figure 3. The effects of cadmium (Cd) on chromosomal morphology in root tip cells of barley

microtubules at different stages of cell division. In control root tip cells of barley, we observed some typical arrays of MTs (Fig. 4). Cortical MTs (cMTs) of meristematic cells were rich during interphase. They were observed roughly parallel to each other and were oriented perpendicular to the primary axis of cell expansion (Fig. 4A1-3). The nuclear envelope seemed intact during preprophase. The cMTs gathered together forming a girdle-shaped preprophase band (PPB) around the nucleus (Fig. 4B1-3). During metaphase, the PPB disappeared gradually from cortex and spindle was formed. Spindle consisting of MT bundles was converged to broad poles and bore the chromosomes stringently positioned on the metaphase plate (Fig. 4C1-3). In anaphase cells spindle consisted of shortened kinetochore MTs, which apparently were pulling the sister chromosomes in synchrony to opposing poles (Fig. 4D1-3). The phragmoplast was noted as two opposing short bundles of MTs in the position of the equator at telophase. At this stage it expanded centrifugally, and finally formed regularly along the sides of the new developing cell plate (Fig. 4E1-3).

Effects of cadmium on the organization of MT cytoskeleton in mitotic cells. Obvious alterations

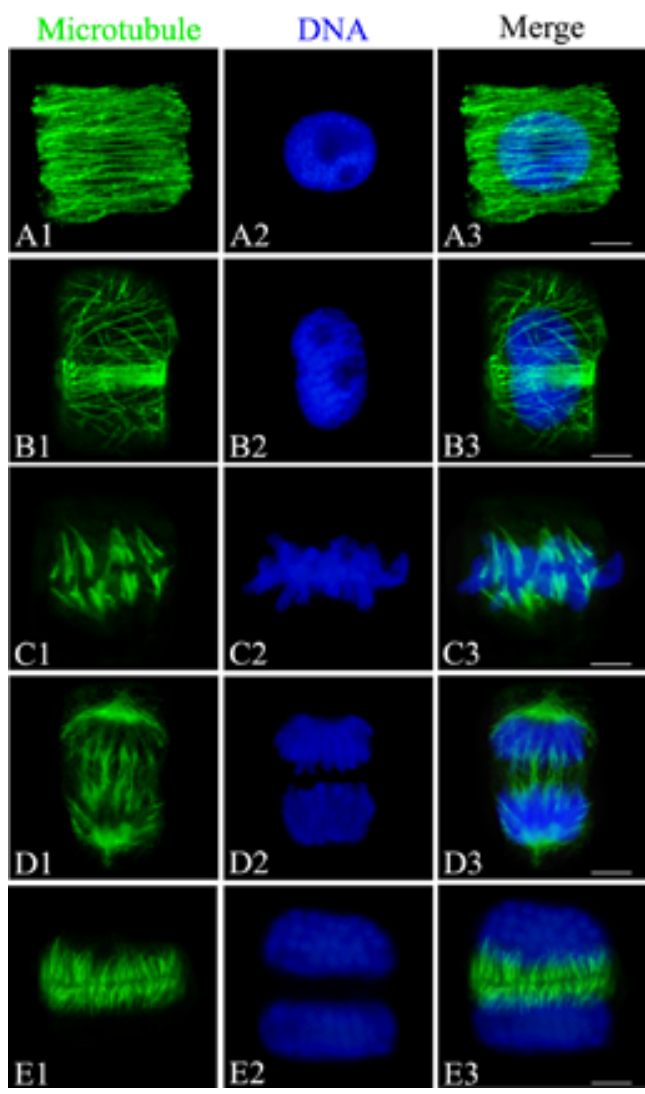

Notes. Tubulin immunolabelling (A1-E1), DNA staining with 4', 6-diamidino-2-phenylindole (DAPI) (A2-E2) and merged images (A3-E3) of normal root tip cells. Interphase: the cMTs appear densely arranged and are orientated transversely to the long cell axis (A), early prophase: preprophase band (PPB) and microtubules focussed on the spindle poles can be distinguished (B), metaphase: chromosome and spindles (C), anaphase: chromosome and spindles (D), telophase: chromosome and phragmoplast MTs (E); scale bars $=10 \mu \mathrm{m}$.

Figure 4. The organization of microtubule (MT) cytoskeleton in control cells

appeared in MTs of mitotic spindle in mitotic cells of barley exposed to cadmium by using immunofluorescence labelling in the present investigation. We observed that 
MT arrangement was closely related to chromosomal aberrations during mitosis under cadmium stress. After cadmium exposure all kinds of abnormal MTs can be observed clearly in mitotic cells. Cadmuim disturbed PPB maturation and resulted in disorganization. Many short MT fragments appeared in the cell periphery and PPB MTs cracked (Fig. 5A1-3). Cadmium interfered with the organization of the MT cytoskeleton as well as tubule polymerization. In this way, cadmium delayed MT disassembly during mitosis and led to the disorder of spindle MTs. At metaphase, although chromosomes could be normally distributed in the central of cell under cadmium stress, spindle fibres were severely disrupted (Fig. 5B1-3). In some cells exposed to cadmium, mitotic spindle MTs lost their organization, and were randomly oriented and scattered in cells and sister chromatids could not be moved to the cell poles, resulting in formation of c-mitosis (Fig. 5C1-3). Anaphases were abnormal in some dividing cells: mitotic spindle MTs lost their organization, were randomly oriented and stuck to each other (Fig. 5D1-3). Also, we observed that MTs were discontinuous and formed into numerous short

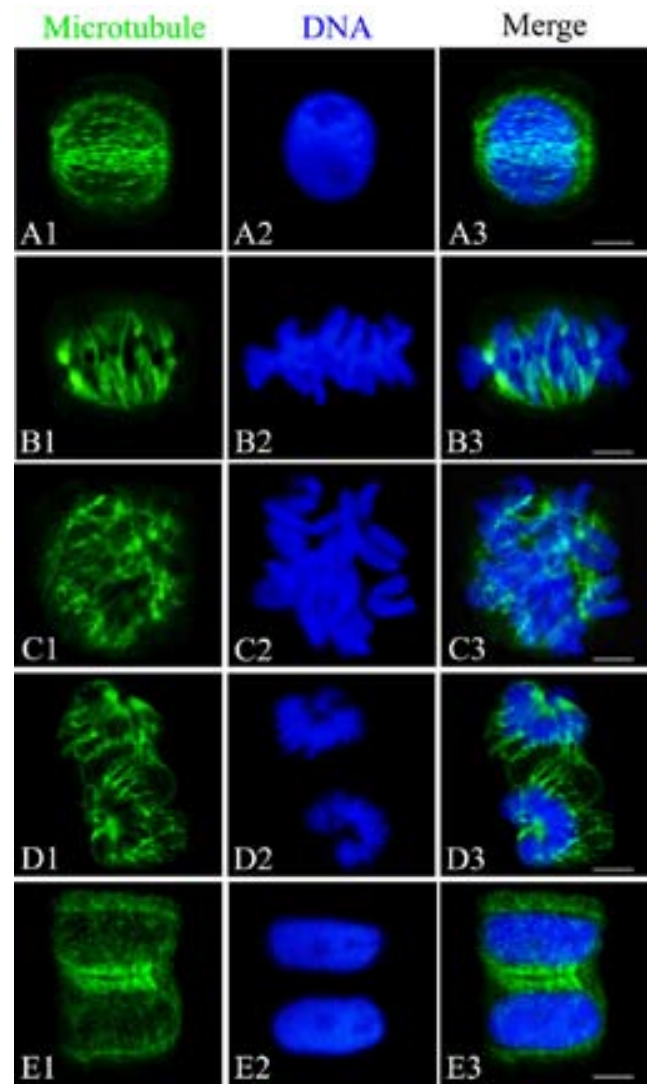

Notes. Tubulin immunolabelling (A1-E1), DNA staining with 4', 6-diamidino-2-phenylindole (DAPI) (A2-E2) and merged images (A3-E3) of the treated root tip cells. Showing many short MT fragments appearing in the cell periphery and preprophase band (PPB) MTs cracked (10 $\mu \mathrm{M} \mathrm{Cd}, 48 \mathrm{~h})(\mathrm{A})$, showing spindle fibres severely disrupted $\mathrm{S}(50 \mu \mathrm{M} \mathrm{Cd}, 24 \mathrm{~h})$ (B), showing spindle MTs randomly oriented and scattered in the cells with c-mitosis $(10 \mu \mathrm{M} \mathrm{Cd}, 48 \mathrm{~h})(\mathrm{C})$, showing spindle MTs randomly oriented and stuck into each other $(50 \mu \mathrm{M} \mathrm{Cd}$, $24 \mathrm{~h}$ ) (D), showing the phragmoplast partly depolymerized in telophase cells $(50 \mu \mathrm{M} \mathrm{Cd}, 48 \mathrm{~h})(\mathrm{E})$; scale bars $=10 \mu \mathrm{m}$.

Figure 5. Effects of cadmium $(\mathrm{Cd})$ on the organization of microtubule (MT) cytoskeleton in the root tip cells exposed to different concentrations of cadmium and treatment times
MT fragments and lumps in the cells after cadmium treatment, which disturbed the formation of phragmoplast in telophase (Fig. 5E1-3).

Effects of cadmium on the organization of MT cytoskeleton in interphase cells. Cadmium could cause the alterations in the organization of microtubular cytoskeleton in barley cells. The MT arrays are very sensitive to cadmium, and their sensitivity depends on the cadmium concentration and the duration of exposure. At low cadmium concentration $(10 \mu \mathrm{M})$ some cells displaying aberrant cMTs were noted after cadmium exposure for $24 \mathrm{~h}$. MT organization was traversed by slightly irregular wavy in these cells (Fig. 6A1-3). Up to $10 \mu \mathrm{M} \mathrm{Cd}$ for $48 \mathrm{~h}$, interphase cMTs of some cells lost their transverse organization. Instead, they were randomly oriented, often discontinuous and formed a small amount of discontinuous fragments of different size at the cell periphery (Fig. 6B1-3, C1-3). The proportion of abnormal MTs varied with the different concentrations used and duration of treatment. At $50 \mu \mathrm{M} \mathrm{Cd}$ for $48 \mathrm{~h}$, interphase cMTs were randomly oriented and more MTs were discontinuous, forming numerous short MT fragments (Fig. 6D1-3). At $50 \mu \mathrm{M}$ Cd for $72 \mathrm{~h}$ or $100 \mu \mathrm{M}$ $\mathrm{Cd}$ for $24 \mathrm{~h}$, severely toxic phenomenon was observed: disordered MTs were splintered into discontinuous wavy ones and MTs stick each other, forming lumps where

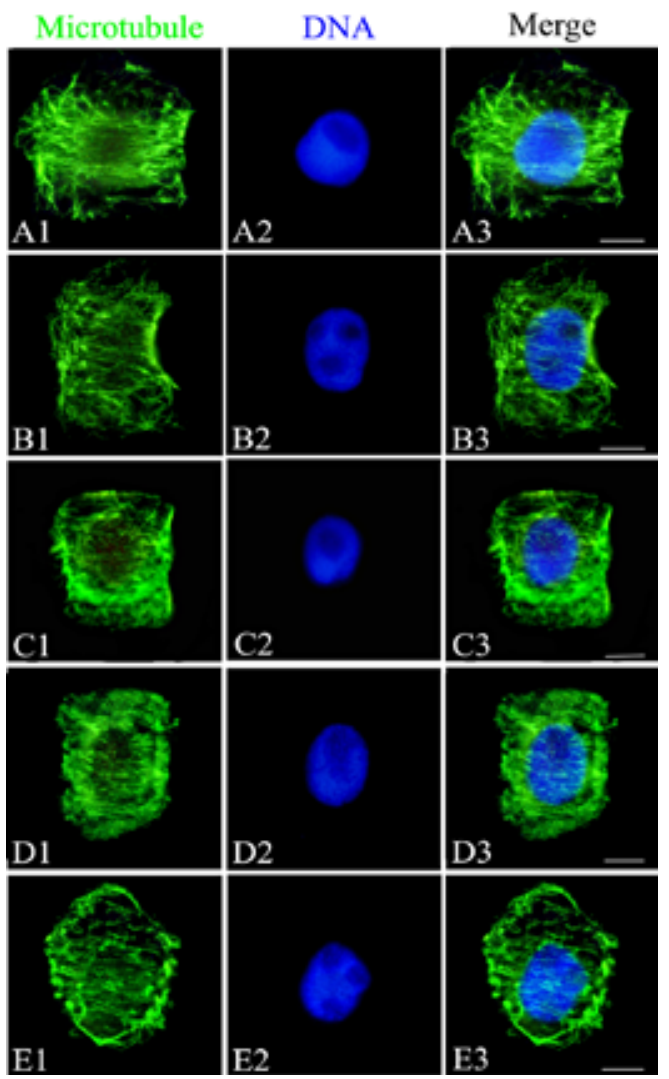

Notes. Tubulin immunolabelling (A1-E1), DNA staining with 4', 6-diamidino-2-phenylindole (DAPI) (A2-E2) and merged images (A3-E3) of the treated root tip cells. Showing aberrant cMTs with slightly skewed wavy $(10 \mu \mathrm{M} \mathrm{Cd}, 24 \mathrm{~h})(\mathrm{A})$, showing cMTs randomly oriented and a small amount of discontinuous fragments $(10 \mu \mathrm{M} \mathrm{Cd}, 48 \mathrm{~h})(\mathrm{B}-\mathrm{C})$, showing numerous short MT fragments $(50 \mu \mathrm{M} \mathrm{Cd}, 48 \mathrm{~h})(\mathrm{D})$, showing MT stickiness and depolymerized MTs arrays $(100 \mu \mathrm{M} \mathrm{Cd}, 24 \mathrm{~h})(\mathrm{E})$; scale bars $=10 \mu \mathrm{m}$

Figure 6. Effects of cadmium (Cd) on the organization of microtubule (MT) cytoskeleton in interphase cells 
MTs arrays were mostly depolymerized (Fig. 6E1-3). Evidence above suggested that cadmium damaged structure of cMTs and even resulted in cell death.

\section{Discussion}

It has been known that plant roots are one of the most sensitive organs to environmental stresses. The roots are the sole organs penetrating the soil and come into direct contact with heavy metals. Excessive cadmium often results in environmental contamination. Therefore, the understanding cadmium uptake and accumulation sites in roots and the evaluation of action mechanisms of cadmium toxic to plant root tip cells and their consequences on mitotic index, chromosomes and microtubule cytoskeleton, as performed in the present investigation, are very important.

Fluorescent cadmium reagent is rarely used in plant studies. Cadmium ions can bind strongly to $\mathrm{SH}-$ containing enzymes/proteins inside the cell. Leadmium ${ }^{\mathrm{TM}}$ Green AM dye has higher affinity for cadmium than internal proteins (Javed et al., 2014) and is not sensitive to other divalent ions except for lead. The uptake of cadmium into root cells of barley using the Cd-sensitive dye Leadmium $^{\mathrm{TM}}$ Green AM was investigated. Green fluorescence representing the binding of the dye to cadmium was observed in elongation zone after cadmium exposure for $1 \mathrm{~h}$, suggesting that elongation zone is primary site of cadmium uptake and accumulation. Then the fluorescence labelling cadmium extends up to mature zone and down to meristematic zone gradually, indicating that meristem, elongation and mature zone in roots of barley can absorb and accumulate cadmium. The results here supported our previous observation where cadmium was found to be absorbed within hours in the root cells of a Allium sativum exposed to cadmium (Jiang et al., 2009). Cao et al. (2014), using Leadmium ${ }^{\mathrm{TM}}$ Green AM, found that preferential localization of cadmium was in root apex of the root tips of Cd-tolerant genotype 'Weisuobuzhi' in barley exposed to cadmium, suggesting that this effect was more pronounced with increasing cadmium concentration.

It is well known that meristems located in root tips are involved primarily in extension of plant body, and they refer to a population of cells composed of initials and their immediate derivatives. Most of the cell divisions in plants occur in and near the meritems. Plant growth is accomplished by a combination of cell division and cell enlargement, where the elongation of cells in this region results in most of the increase in the root length. This developmental pathway, however, is influenced greatly by environmental factors such as heavy metals (Jiang et al., 2014).

The results here indicated that $\mathrm{Cd}$-exposure significantly inhibited the mitotic index in barley root tip bioassay in a concentration-dependent manner. Under cadmium stress, the mitotic index changed in good agreement with the decline of root growth. Cadmium was accumulated predominantly in the meristem where it disturbed cell division. This is supported by the data from the Leadmium ${ }^{\mathrm{TM}}$ Green AM dye test that cadmium ions are absorbed and accumulated mainly in meristem and elongation zone in the roots of barley exposed to cadmium for 24 to $48 \mathrm{~h}$ periods of treatment. The results indicated that cadmium concentration increase from 50 to $100 \mu \mathrm{M}$ did not change the mitotic index, suggesting that $50 \mu \mathrm{M} \mathrm{Cd}$ was the critical or lethal concentration, which can inhibit cell division significantly. According to Fusconi et al. (2007), the reduction in the number of mitotic cells under cadmium exposure could be due to its interference with cell cycle progression. Fusconi et al. (2007) and Hattab et al. (2009) indicated that the disturbance in the mitotic activity could occur due to inhibition of DNA synthesis or a blocking in the $\mathrm{G}_{2}$ phase of the cell cycle, preventing the cell from entering mitosis. Amirthalingam et al. (2013) found that the drastic reduction in mitotic index in the root tip cells of Vigna unguiculata after cadmium stress due to $\mathrm{Cd}$-induced genotoxicity, suggesting that increased production of reactive oxygen species (ROS) under cadmium toxicity serves as a major source of DNA damage leading to strand breakage, removal of nucleotides and a variety of modifications in organic bases of nucleotides. Cadmium induced genotoxic effects, including C-mitosis, chromosome bridges and sticky chromosomes in the root tip cells of barley. Cytotoxic effects were observed as mitodepressive activity. C-mitosis is more often observed in low concentration of cadmium, reflecting slight or moderate cytological toxicity (Levan, 1938). Chromosome bridges are considered as a type of moderate and reversible toxicity. The sticky chromosomes were often observed in the root tip cells exposed to high (50 to $100 \mu \mathrm{M}) \mathrm{Cd}$ concentrations, which reflects high toxic effects, usually of an irreversible type, and probably leads to cell death. The sticky chromosome arises from improper folding of the chromosome fibre into single chromatids and chromosomes become attached to each other by means of subchromatid bridges (McGill et al., 1974; Klásterá et al., 1976). The data presented here clearly demonstrated that cadmium had a toxic effect on root growth of barley when compared with the control, which is in good agreement with the findings by Zhang et al. (2009) and Shi et al. (2014). Some investigations indicated that cadmium caused the inhibition of root elongation by metal interference with cell division, including inducement of chromosomal aberrations and abnormal mitosis (Fusconi et al., 2007; Zhang et al., 2009). These phenomena are thought to be associated with damage of microtubule arrays. It has been already demonstrated that some chromosomal aberration may occur by non direct genotoxic effect. Cadmium is known to have indirect effects on DNA, causing strand breaks, sister chromatid exchanges, chromosomal aberrations (Cao et al., 2014; El-Habit, Moneim, 2014). Cadmium inhibited cell division and cell expansion growth, resulting in inhibition of root growth and appearance of stunted roots (Zhang et al., 2009). Some damage induced by cadmium can inhibit DNA repair mechanisms by competition with certain ions which are essential for DNA polymerases (Cao et al., 2014).

Immunodetection of tubulins has been used to characterize cytological changes induced by heavy metals. Cadmium attacked microtubule arrays during interphase and cell division. The interphase cortical microtubule arrays appeared affected even at low concentration of $\mathrm{Cd}$ $(10 \mu \mathrm{M})$. Some reports indicated that there were similar patterns of microtubule alterations after metal stress in Allium cepa and Spirogyra decimina interphase cells (Přibyl et al., 2005; Xu et al., 2009). The results presented in this investigation confirm that cadmium can affect microtubule architecture by inducing aberrant spindle formation or disruption of microtubule arrays in the mitotic cells in root apical meristems of barley. In mitotic cells, the preprophase band and prophase spindle are also disturbed. Cadmium disrupts metaphase and anaphase spindles, impairing chromosome segregation. The cytokinetic phragmoplast is perturbed by cadmium as well. Hence, it is concluded that microtubule arrays in root cells of barley are affected in all mitotic stages and in cytokinesis, suggesting that microtubule cytoskeleton may be a cellular 
target of cadmium toxicity and tolerance in plants.

Propidium iodide is an intercalating agent and a fluorescent molecule that can be used to stain DNA, which is an alternative agent to study cell membrane damage (Liao et al., 2011). Morphological changes in the cells may be related to damage to the integrity of the cell membrane (Liao et al., 2010). Here, we can confirm that cadmium has toxic effect on the cell membrane damage in the root tip cells of barley using propidium iodide staining. It is interesting to note that the cell damage was observed in the elongation zone of root tips exposed to cadmium for $1 \mathrm{~h}$ (Fig. 2II). The propidium iodide staining data here are in good agreement with the evidence obtained from cadmium absorption in the different zones in the roots of barley under cadmium stress, suggesting that the absorption and accumulation of cadmium and the cell death have obvious relevance in the roots exposed to cadmium. Lipid peroxidation can be a first indication of oxidative damage. The plant plasma membrane is considered to be the first living structure affected by cadmium toxicity (Gallego et al., 2012). Exposure to cadmium generates various reactive oxygen species (ROS) in plant cells, including $\mathrm{H}_{2} \mathrm{O}_{2}$, usually metabolized into water and oxygen in the presence of catalase (Zhang et al., 2009). $\mathrm{H}_{2} \mathrm{O}_{2}$ can cause harmful hydroxyl radicals $\left(\mathrm{OH}^{-}\right)$, induce lipid peroxidation of cell membranes, and eventually lead to irreversible membrane damage (Opdenakker et al., 2012). Cadmium exerts its toxicity through membrane damage and inactivation of enzymes (Shah, 2011). The former investigation reported that the inhibition of root growth was due to excess $\mathrm{Cd}$-induced changes in plasma membrane integrity in barley root cells (Tamas et al., 2006). Data (unpublished) indicated that cadmium could induce the increase of the malondialdehyde content in roots of barley exposed to cadmium when compared to the control, suggesting that cadmium can generate the production of a powerful oxidation which in turn brings about lipid peroxidation (Hatata, Abdel-Aal, 2008). Zou et al. (2012) indicated that cadmium also induced the formation of ROS. Cao et al. (2014) demonstrated that Cdtolerant genotype 'Weisuobuzhi' in barley is more capable of scavenging Cd-induced ROS.

\section{Conclusions}

Based on the information provided in this article, it is concluded that:

1. Cadmium $(\mathrm{Cd})$ firstly enters elongation zone cells in root tips of barley. The roots are the main sites of cadmium uptake in the Cd-polluted soil.

2. The degree of the cell damage in the root tips is associated with the amounts of cadmium absorption and accumulation.

3. Cadmium can disturb mitosis in root tips, inhibit mitotic index (MI) and induce chromosome aberration.

4. Cadmium directly affected tubulin polymerization, disturbing normal microtubule (MT) organization in the meristematic cells exposed to cadmium.

\section{Acknowledgements}

This project was supported by the National Natural Science Foundation of China (grant number 30972331). The authors wish to express their appreciation to the reviewers for this paper.

Received 09102015

Accepted 17022016

\section{References}

Alloway B. J. 1995. Cadmium. Alloway B. J. (ed.). Heavy metals in soils. Glasgow, Scotland, p. 122-151

Amirthalingam T., Velusamy G., Pandian R. 2013. Cadmiuminduced changes in mitotic index and genotoxicity on Vigna unguiculata (Linn.) Walp. Journal of Environmental Chemistry and Ecotoxicology, 5: 57-62

Andrioli N. B., Soloneski S., Larramendy M. L., Mudry M. D. 2012. Cytogenetic and microtubule array effects of the zineb-containing commercial fungicide formulation Azzurro ${ }^{\circledR}$ on meristematic root cells of Allium cepa $\mathrm{L}$. Mutation Research. 742: 48-53 http://dx.doi.org/10.1016/j.mrgentox.2011.11.014

Cao F. B., Chen F., Sun H. Y., Zhang G. P., Chen Z. H., Wu F. B. 2014. Genome-wide transcriptome and functional analysis of two contrasting genotypes reveals key genes for cadmium tolerance in barlev. BMC Genomics, 15: 611 http://dx.doi.org/10.1186/1471-2164-15-611

Das P., Samantaray S., Rout G. R. 1997. Studies on cadmium toxicity in plants: a review. Environmental Pollutution, 98: $29-36$ http://dx.doi.org/10.1016/S0269-7491(97)00110-3

El-Habit O. H., Moneim A. E. A. 2014. Testing the genotoxicity, cytotoxicity, and oxidative stress of cadmium andnickel and their additive effect in male mice. Biological Trace Element Research. 159: 364-372 http://dx.doi.org/10.1007/s12011-014-0016-6

Fusconi A., Gallo C., Camusso W. 2007. Effects of cadmium on root apical meristems of Pisum sativum L.: cell viability, cell proliferation and microtubule pattern as suitable markers for assessment of stress pollution. Mutation Research-Genet Toxicology Environmental Mutagenesis, 632: 9-19 http://dx.doi.org/10.1016/j.mrgentox.2007.03.012

Gallego S. M., Pena L. B. Barcia R. A., Azpilicueta C. E., Iannone M. F., Rosales E. P., Zawoznik M. S., Groppa M. D., Benavides M. P. 2012. Unravelling cadmium toxicity and tolerance in plants: insight into regulatory mechanisms Environmental and Experiment Botany, 83: 33-46

Hatata M. M., Abdel-Aal E. A. 2008. Oxidative stress and antioxidant defense mechanisms in response to cadmium treatments. American-Eurasian Journal of Agricultural and Environmental Sciences, 4: 655-669

Hattab S., Chouba L., Ben Kheder M., Mahouachi T. Boussetta H. 2009. Cadmium-and copper-induced DNA damage in Pisum sativum roots and leaves as determined by the Comet assay. Plant Biosystems, 143: suppl. S6-11

Hepler P. K., Hush J. M. 1996. Behavior of microtubules in living plant cell. Plant Physiology, 112: 455-461

Javed M. T., Lindberg S., Greger M. 2014. Cadmium uptake in Elodea canadensis leaves and its interference with extraand intra-cellular $\mathrm{nH}$. Plant Biologv, 16: 615-21 http://dx.doi.org/10.1111/plb.12086

Jiang W. S., Liu D. H., Xu P. 2009. Cd-induced system of defence in the garlic root meristematic cells. Biologia Plantarum. 53: 369-372 http://dx.doi.org/10.1007/s10535-009-0069-0

Jiang Z., Qin R., Zhang H. H., Zou J. H., Shi Q. Y., Wang J. R., Jiang W. S., Liu D. H. 2014. Determination of Pb genotoxic effects in Allium cepa root cells by fluorescent probe, microtubular immunofluorescence and comet assay. Plant and Soil. 383: 357-372 http://dx.doi.org/10.1007/s11104-014-2183-9

Klásterá I., Natarajan A. T., Ramel C. 1976. An interpretation of the origin of subchromatid aberrations and chromosome stickiness as a category of chromatid aberrations. Hereditas, 83: $153-162$ http://dx.doi.org/10.1111/j.1601-5223.1976.tb01581.x

Levan A. 1938. The effect of colchicine on root mitoses in Allium. Hereditas. 24: 471-486 http://dx.doi.org/10.1111/j.1601-5223.1938.tb03221.x

Liao I., Shi Y., Jia R., Wang L. 2010. Sensitivity of different cytotoxic responses of Vero cells exposed to organic chemical pollutants and their reliability in the biotoxicity test of trace chemical pollutants. Biomedical and Environmental Sciences, 23: 219-229 http://dx.doi.org/10.1016/S0895-3988(10)60056-6 
Liao T. T., Jia R. W., Shi Y. L., Jia J. W., Wang L., Chua H. 2011. Propidium iodide staining method for testing the cytotoxicity of 2,4,6-trichlorophenol and perfluorooctane sulfonate at low concentrations with Vero cells. Journal of Environmental Science and Health, Part A, 46: 1769-1775

Liu D. H., Kottke I., Adam D. 2007. Localization of cadmium in the root cells of Allium cepa by energy dispersive X-ray analysis. Biologia Plantarum, 51: 363-366 http://dx.doi.org/10.1007/s10535-007-0075-Z

Liu D. H., Xue P., Meng Q. M., Zou J., Gu J. G., Jiang W. S. 2009. $\mathrm{Pb} / \mathrm{Cu}$ effects on the organization of microtubule cytoskeleton in interphase and mitotic cells of Allium sativum L. Plant Cell Renort. 28: 695-702 http://dx.doi.org/10.1007/s00299-009-0669-3

McGill M., Pathan S., Hsu T. C. 1974. Effects of ethidium bromide on mitosis and chromosomes: a possible material basis for chromosome stickness. Chromosoma, 47: 157-164 http://dx.doi.org/10.1007/BF00331803

Opdenakker K., Remans T., Keunen E., Vangronsveld J., Cuypers A. 2012. Exposure of Arabidopsis thaliana to Cd or $\mathrm{Cu}$ excess leads to oxidative stress mediated alterations in MAPKinase transcript levels. Environmental and Fxnerimental Rotany. 83: 53-61 http://dx.doi.org/10.1016/j.envexpbot.2012.04.003

Özkara A., Akyil D., Erdoğmuş K. M. 2011. Evaluation of germination, root growth and cytological effects of wastewater of sugar factory (Afyonkarahisar) using Hordeum vulgare bioassays. Environmental Monitoring and Assessment. 183: 517-524 http://dx.doi.org/10.1007/s10661-011-1936-7

Přibyl P., Cepák V., Zachleder V. 2005. Cytoskeletal alterations in interphase cells of the green alga Spirogyra decimina in response to heavy metals exposure. I. The effect of cadmium. Protonlasma. 226: 231-240 http://dx.doi.org/10.1007/s00709-005-0123-5

Qin R., Jiang W. S., Liu D. H. 2013. Cadmium can induce alterations in the cellular localization and expression of three major nucleolar proteins in root tip cells of Vicia faba I. Plant and Soil. 368: 365-373

http://dx.doi.org/10.1007/s11104-012-1523-x
Sanità di Toppi L., Gabbrielli R. 1999. Response to cadmium in higher plants. Environmental and Experimental Botany, 41: 105-130 http://dx.doi.org/10.1016/S0098-8472(98)00058-6

Shah K. 2011. Cadmium metal detoxification and hyperaccumulators. Detoxification of heavy metals. Sherameti I., Varma A. (eds.). Series Soil Biology, vol. 30. Berlin, Germany, n. 181-230 http://dx.doi.org/10.1007/978-3-642-21408-0 10

Shi H. P., Feng Y., Wang Y. L., I'sang P. K. E. 2014. Effect of cadmium on cytogenetic toxicity in hairy roots of Wedelia trilobata L. and their alleviation by exogenous $\mathrm{CaCl}_{2}$. Environmental Science and Pollution Research, 21: $1436-1443$ http://dx.doi.org/10.1007/s11356-013-2015-0

Tamas L., Becoba B., Huttova J., Mistrik I., Olle M. 2006. Cadmium induced inhibition of apoplastic ascorbate oxidase in barley roots. Plant Growth and Regulation, 48: $41-49$ http://dx.doi.org/10.1007/s10725-005-4747-4

Wasteneys G. O., Galway M. E. 2003. Remodelling the cytoskeleton for growth and form: an overview with some new views. Annual Review of Plant Biologv. 54: 691-722. http://dx.doi.org/10.1146/annurev.arplant.54.031902.134818

Xu P., Liu D., Jiang W. 2009. Cadmium effects on the organization of microtubular cytoskeleton in interphase and mitotic cells of Allium sativum. Biologia Plantarum, 53: 387-390 http://dx.doi.org/10.1007/s10535-009-0073-4

Zhang S. S., Zhang H. M., Qin K., Jiang W. S., Liu D. H. 2009. Cadmium induction of lipid peroxidation and effects on root tip cells and antioxidant enzyme activities in Vicia faha L. Ecotoxicology, 18: 814-823 http://dx.doi.org/10.1007/s10646-009-0324-3

Zou J. H. Yue J. Y., Jiang W. S., Liu D. H. 2012. Effects of cadmium stress on root tip cells and some physiological indexes in Allium cepa var. agrogarum L. Acta Biologica Cracoviensia, Series Botanica, 54: 129-141 http://dx.doi.org/10.2478/v10182-012-0015-x

ISSN 1392-3196 / e-ISSN 2335-8947

Zemdirbyste-Agriculture, vol. 103, No. 2 (2016), p. 151-158

DOI $10.13080 /$ z-a.2016.103.020

\title{
Kadmio lokalizacija ir toksinis poveikis miežių šaknų augimo zonoje
}

\author{
Q. Shi ${ }^{1}$, J. Wang ${ }^{1}$, J. Zou ${ }^{1}$, Z. Jiang ${ }^{2}$, H. Wu ${ }^{1}$, J. Wang ${ }^{1}$, W. Jiang ${ }^{1}$, D. Liu ${ }^{1}$ \\ ${ }^{1}$ Tianjin Normal universiteto Gyvybės mokslų koledžas, Kinija \\ ${ }^{2}$ Tianjin eksperimentinè vidurinè mokykla, Kinija
}

\section{Santrauka}

Siekiant geriau suprasti kadmio (Cd) toksiškumą ir toleranciją jam, buvo tirtas kadmio toksinis poveikis miežių šaknų galiukų ląstelèms jas skirtingą laiką veikiant ịvairiomis kadmio koncentracijomis. Tyrimo rezultatai parodè, kad šaknys buvo pagrindinè augalo dalis, ịsisavinanti kadmị. Kadmio jonai pirmiausia prasiskverbe ị šaknų tịsimo zonos ląsteles ir kaupési šioje srityje, po to keliavo aukštyn ị brendimo ir toliau ị meristemos zonas. Saknų galiukų ląsteliu pažeidimo laipsnis yra susijęs su absorbuoto kadmio kiekiu ir jo susikaupimu. Po to, kai kadmio jonai pateko ị meristemos zoną, buvo sutrikdyti mechanizmai, kontroliuojantys citoskeleto mikrovamzdelių ir tubulino sąrankos arba pasiskirstymo procesus. Susiformavo anomalūs mikrovamzdeliu rinkiniai, taip pat sutrūkę banguoti mikrovamzdeliai ir jų trumpi fragmentai ląstelès periferijoje. Dẻl kadmio toksinio poveikio sumažèjo mitotinis indeksas ir padidejjo atipinès mitozès susidarymas, indukuojantis netipiškas chromosomas, pavyzdžiui, C-mitozè, anafazès tiltai ir chromosomų sulipimas. Todėl galima teigti, kad augalo šaknų galiukų ląstelèse kadmis pažeidžia citoskeleto mikrovamzdelius. Tiesioginis kadmio toksinis poveikis ląstelès lygmenyje miežių šaknų galiukams, įrodytas šio tyrimo metu, yra gali būti panaudotas vertinant metalų toksiškumo ir tolerancijos mechanizmą.

Reikšminiai žodžiai: Hordeum vulgare, Leadmium ${ }^{\mathrm{TM}}$ Green AM, mikrovamzdeliai, mitozè, propidiumo jodidas.

Please use the following format when citing the article:

Q. Shi, J. Wang, J. Zou, Z. Jiang, H. Wu, J. Wang, W. Jiang, D. Liu. 2016. Cadmium localization and its toxic effects on root tips of barley. Zemdirbyste-Agriculture, 103 (2): 151-158 DOI 10.13080/z-a.2016.103.020 